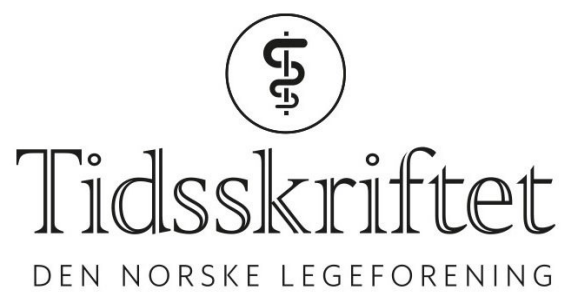

\title{
Rettelse: Fuktighetskrem og oljebad forebygger ikke atopisk eksem
}

RETTELSE

EVA MARIA REHBINDER

HÅVARD O. SKJERVEN

KARIN C. LØDRUP CARLSEN

Tidsskr Nor Legeforen 2021; 141: 111-2.

I Tidsskriftet nr. 2/2021, s. 111 skal det stå: Håvard O. Skjerven er ph.d. og overlege ved Barneavdeling for allergi- og lungesykdommer og Klinisk forskningspost for barn ved Oslo universitetssykehus.

Vi beklager feilen, den er rettet på nett.

Publisert: 22. februar 2021. Tidsskr Nor Legeforen. DOI: 10.4045/tidsskr.21.0095

(C) Tidsskrift for Den norske legeforening 2020. Lastet ned fra tidsskriftet.no 